
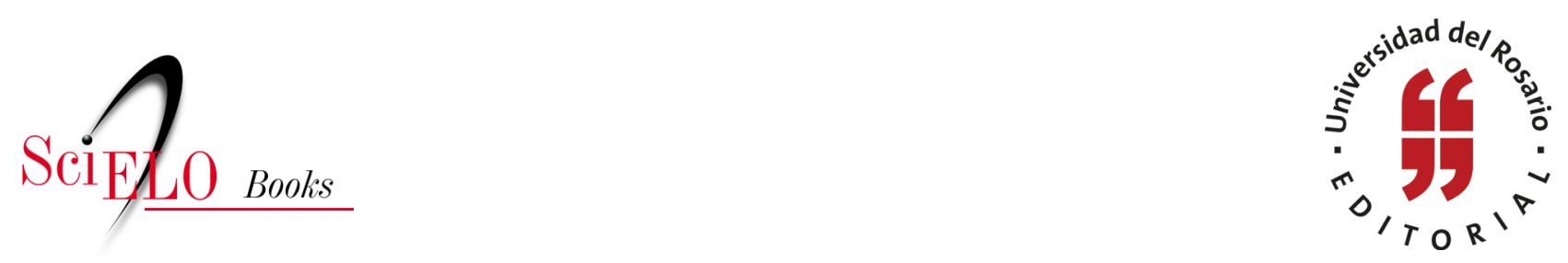

\title{
35. La mamita está borracha
}

\author{
César Augusto Tapias Hernández
}

\section{SciELO Books / SciELO Livros / SciELO Libros}

TAPIAS HERNÁNDEZ, C.A. La mamita está borracha. In: Historias de familia: Etnografía delirante sobre el amor, la violencia y las drogas [online]. Bogotá: Editorial Universidad del Rosario, 2014, pp. 151-152. Textos de ciencias humanas collection. ISBN: 978-958-738-543-4.

https://doi.org/10.7476/9789587385434.0036.

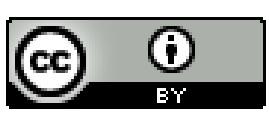

All the contents of this work, except where otherwise noted, is licensed under a Creative Commons Attribution 4.0 International license.

Todo o conteúdo deste trabalho, exceto quando houver ressalva, é publicado sob a licença Creative Commons Atribição 4.0.

Todo el contenido de esta obra, excepto donde se indique lo contrario, está bajo licencia de la licencia $\underline{\text { Creative }}$ Commons Reconocimento 4.0 . 


\section{La mamita está borracha}

Para obviar estos peligros, lo mejor para mi es, creo, buir. François Villon, Poesía

Fernando (el papá de Fred, JF y Mónica) y yo la subimos hacia su habitación.

Insistentemente, ella no deja de decir: "No me vayan a dejar caer. No me vayan a dejar caer... No me vayan a dejar caer. No me vayan a dejar caer. Ay, juemadre... No me vayan a dejar caer".

$\infty \infty \infty$

Con este texto he querido compartir algunas de las historias que me constituyen como individuo y como miembro de un grupo. Quedan revelados aquí nuestros pensamientos y la forma de comunicación que empleamos. Son reflexiones en torno a la dialéctica individuo-sociedad, puestas en una plataforma global para considerar a la sociedad a través del microuniverso que es la familia, en cuanto conjunto de interacciones, de asociaciones entre sujetos, de relaciones sociales. Una serie de aspectos relacionados con términos como identidad social, grupos sociales, roles sociales, sistemas simbólicos y, por supuesto, construcción de sentido. Para cerrar, en palabras de Alfred Schütz, quiero reiterar que esta etnografía nos ha servido para reconocer que:

$\mathrm{Al}$ vivir en el mundo, vivimos con otros y para otros, y orientamos nuestras vidas hacia ellos. Al vivenciarlos como otros, como contemporáneos y congéneres, como predecesores y sucesores, al unirnos con ellos en la actividad y el trabajo común, influyendo sobre ellos y recibiendo a nuestra vez su influencia, al hacer 
Historias de familia

todas estas cosas, comprendemos la conducta de los otros y suponemos que ellos comprenden la nuestra (1979, p. 39). 